\begin{tabular}{l|l}
\hline SISTEMA \\
ELETRONICO \\
DE REVISTAS \\
SER I UFPR \\
unw.ser.ufpr.br
\end{tabular}

\title{
Lixo Zero - Gestão de resíduos sólidos para uma sociedade mais próspera
}

\section{Zero Waste - Solid waste management for a more prosperous society}

\begin{abstract}
Abramovay, Ricardo; Speranza, Juliana Simões; Petitgand, Cécile. Lixo Zero-Gestão de resíduos sólidos para uma sociedade mais próspera. São Paulo: Planeta Sustentável; Instituto Ethos, 2013. 77 p. ISBN 978-85-364-1615-1
\end{abstract}

\author{
Daniela Fideles da SILVA ${ }^{1 *}$ \\ ${ }^{1}$ Universidade de Brasília (UnB), Brasília, DF, Brasil. \\ *E-mail de contato: daniela.fideles@gmail.com
}

Resenha recebida em 2 de dezembro de 2013, versão final aceita em 24 de julho de 2014.

Esta obra recente aborda a discussão emergente sobre a situação do lixo no país, em um momento em que o assunto é crucial. Trata-se de um momento de transição, da instauração da gestão de resíduos sólidos a partir de um novo marco legal, a Política Nacional de Resíduos Sólidos - PNRS, criada pela Lei 12.305 de 2 de agosto de 2010.

A proposta do livro é avaliar a gestão de resíduos, observando o seu funcionamento atual e as suas possibilidades futuras. Neste sentido, o Brasil ocupa uma situação peculiar no que diz respeito aos fatores principais que determinam os caminhos a serem seguidos. O livro compara o país, enquanto país em desenvolvimento, com países desenvolvidos. Ficam evidentes as diferenças com relação às tipologias dos resíduos gerados, às quantidades e principalmente à postura relativa à reciclagem e aos personagens fundamentais neste processo, os catadores de materiais recicláveis.

Todos os dados obtidos a partir do paralelo com outros locais dão ao leitor a percepção de que a problemática é decorrente de uma alteração comportamental e cultural inerente a países em desenvolvimento, pouco explorada no livro. A comparação da evolução temporal interna também evidencia isto, porque em uma década a população do país aumentou $1 \%$, enquanto a geração de lixo cresceu $6 \%$. A necessidade de alteração de comportamento da indústria é abordada quando se expõe a PNRS, enfatizando os benefícios da logística reversa e da responsabilidade conjugada sobre a geração do lixo.

Um diferencial é a abordagem não da gestão ou do gerenciamento de resíduos, mas da governança, com a observação do papel dos atores. Ao abordar sob 
esta perspectiva, transfere-se para todos os envolvidos a responsabilidade do poder público de resolver todos os problemas.

No entanto, em algumas experiências internacionais tratadas na abordagem de governança, os autores evidenciam algumas ações que não estão calcadas na diminuição da produção de lixo e sim nas iniciativas de sua revalorização, com o foco na utilização em outros produtos. Obviamente, este tipo de ação reduz a destinação do lixo para aterros e incineradores e estimula o reuso dos materiais, mas não dialoga com a necessidade de se reduzir a demanda de recursos naturais e nem com a mudança comportamental da sociedade de consumo.

As experiências internacionais em que se responsabiliza o produtor e o consumidor monetariamente mostram ações sistemáticas para a redução da produção de resíduos. Estimulam, de um lado, o produtor a receber os resíduos gerados por seus produtos e, de outro, estimulam o consumidor a demandar produtos que gerem menos resíduos. Neste aspecto, é abordado o princípio do poluidor-pagador adotado pelo país, por meio da PNRS.

A realidade nacional de governança em resíduos sólidos é de ajuste a uma lei que levou duas décadas para se consolidar. Ainda há o borbulhar de mecanismos legais para regular as responsabilidades e ajustar à nova ordem. Neste sentido, o livro traz a dicotomia entre responsabilidades, em que, de um lado, o Estado é responsável pela destinação adequada e tem debates internos sobre responsabilidades (municípios e estados) e, de outro lado, os demais personagens também precisam se ajustar: o personagem produtor/importador e o personagem consumidor. Revolucionariamente, outro personagem é trazido pela PNRS: os catadores de materiais recicláveis como agentes ambientais.

A avaliação da governança dos resíduos sólidos em âmbito nacional contemplou ainda o mapeamento das legislações existentes por localidade anterior à PNRS e o diálogo entre elas. Como resultado, foi identificada uma harmonia, em geral, entre os assuntos abordados pelas diferentes normas e leis, apesar da intertemporalidade entre elas, com a ocorrência de alguns casos conflitantes no que diz respeito à responsabilidade em sistemas de logística reversa, produtos sujeitos à responsabilidade pós-consumo e definições.
Os desafios impostos são a adesão e a execução da lei, visto que mesmo os municípios e estados que já tinham leis específicas não tiveram efetividade de execução e que ainda é baixa a adesão dos municípios às obrigações legais.

Os catadores de materiais recicláveis merecem atenção especial. O panorama nacional é precário, os catadores e as suas famílias sobrevivem em sua maioria da renda gerada pelo que é coletado e vendido. Mais de $70 \%$ dessas famílias sobrevive com renda familiar inferior a um salário mínimo. A discussão recente dos atores é sobre a valorização destes profissionais enquanto prestadores de serviços ambientais. Em países em que a reciclagem alcança patamares mais altos, estes personagens são elementos fundamentais. A separação de resíduos na fonte, a instalação de processos de logística reversa e a disposição adequada em aterros ou incineradores não dispensam estes profissionais. Uma proposta abordada no texto é organizar a remuneração destes prestadores de serviço.

O livro propõe ações pioneiras que fazem parte da colcha de retalhos para a remuneração. Um exemplo é o crédito de logística reversa, iniciativa dos catadores enquanto protagonistas, mas ainda não inserido formalmente nos acordos setoriais. A proposta é a inserção dos catadores enquanto prestadores de serviços. Eles seriam responsáveis por coletar, fazer a triagem e encaminhar os materiais às empresas que fazem reciclagem; estas, por sua vez, emitiriam um certificado de crédito, que poderia ser comprado pela empresa que tem a responsabilidade sobre a geração do resíduo. A iniciativa, embora com todas as incertezas de efetividade de sistemas de créditos, tem potencial para contribuir com a organização da ainda incipiente execução de logística reversa e integrar os catadores.

O último trecho do livro trata do panorama de logística reversa em pneus, óleos lubrificantes e embalagens de agrotóxicos. Estes materiais já contam com legislação específica e têm os seus processos consolidados. Os dados atualizados evidenciam que é possível executar políticas para resíduos sólidos urbanos, mas que para isso é necessário o mesmo esforço aplicado a estes resíduos específicos.

A obra é recente, traz um bom apanhado da situação geral de resíduos sólidos e da conjuntura política, 
mas não faz uma análise profunda das origens e causas dos problemas, ou mesmo dos caminhos que terá que se percorrer para de fato alcançar o proposto pelo seu título: Lixo Zero. Devido ao caráter generalista, este livro propõe reflexão interessante não apenas para especialistas, mas a todo leitor que se interesse por uma visão mais ampla acerca das transformações recentes da governança de resíduos. 